\title{
Alcohol consumption among students in Vietnam
}

Citation for published version (APA):

Diep, P. B. (2016). Alcohol consumption among students in Vietnam. [Doctoral Thesis, Maastricht University]. https://doi.org/10.26481/dis.20160613pd

Document status and date:

Published: 01/01/2016

DOI:

10.26481/dis.20160613pd

Document Version:

Publisher's PDF, also known as Version of record

\section{Please check the document version of this publication:}

- A submitted manuscript is the version of the article upon submission and before peer-review. There can be important differences between the submitted version and the official published version of record.

People interested in the research are advised to contact the author for the final version of the publication, or visit the DOI to the publisher's website.

- The final author version and the galley proof are versions of the publication after peer review.

- The final published version features the final layout of the paper including the volume, issue and page numbers.

Link to publication

\footnotetext{
General rights rights.

- You may freely distribute the URL identifying the publication in the public portal. please follow below link for the End User Agreement:

www.umlib.nl/taverne-license

Take down policy

If you believe that this document breaches copyright please contact us at:

repository@maastrichtuniversity.nl

providing details and we will investigate your claim.
}

Copyright and moral rights for the publications made accessible in the public portal are retained by the authors and/or other copyright owners and it is a condition of accessing publications that users recognise and abide by the legal requirements associated with these

- Users may download and print one copy of any publication from the public portal for the purpose of private study or research.

- You may not further distribute the material or use it for any profit-making activity or commercial gain

If the publication is distributed under the terms of Article $25 \mathrm{fa}$ of the Dutch Copyright Act, indicated by the "Taverne" license above, 


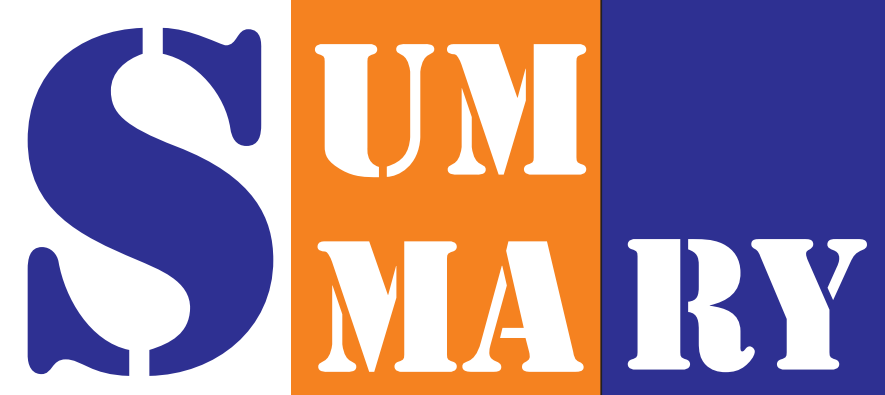


Harmful use of alcohol ranks among the top five risk factors for disease, disability and death throughout the world. Alcohol use is stable or slightly decreasing in developed countries and mostly increasing in developing countries. In Vietnam, a developing country, alcohol consumption per annum of persons aged 15 years and older (both recorded and unrecorded) increased dramatically from about 1.6 liters in 1990 to 6.6 liters in 2010 (this is an increase of $412 \%$ ).

University students, who are mostly aged 18 to 25 years, are in a phase of transition towards adulthood and independence. This period is often associated with risky behavior, such as excessive alcohol consumption. Many studies in developed countries have shown that university students tend to drink more and heavier than their non-university peers. This stresses the necessity to determine the drinking patterns, their consequences and important factors predicting students' alcohol use and to develop effective prevention strategies.

In this thesis, the PRECEDE model is used as a framework to examine the determinants of students' drinking behavior at both the individual and the environmental level. Five studies are presented (Chapters 2-6) which used a crosssectional design and self-reports to examine drinking patterns, their consequences, social demographics, and other relevant determinants. Additionally, the combined influence of expectancies and motives on alcohol consumption, and also the link between two types of individual cognitive determinants and alcohol use, were studied and are presented in Chapter 5. The study in Chapter 6 examined the combined effect of individual and environmental factors on drinking behavior. Data were collected during studies (Chapters 2 to 4 ) among medical students attending Hanoi Medical University (Hanoi, Vietnam). In Chapters 5 and 6, data were collected in three different geographical clusters in Vietnam: i) Hanoi in the north (HN) (the political and cultural capital and central-level city); ii) Ho Chi Minh (HCM) in the south (the most modern and central-level city); iii) Hue in the center (an historic traditional city and provincial-level city), and iv) Buon Me Thuat (BMT) in the highland area of the south (a remote region and provincial-level city). In each of these clusters, data were collected from randomly selected classes of students attending different types of faculties (medicine, economics and technology).

Results on the prevalence of alcohol use are reported in Chapters 2 and 3. More than half of the students drank in the previous year (Chapters 2 and 3) and the prevalence of drinking was about twice as high among male students as compared to female 
students (Chapter 3). However, it appeared that students do not drink frequently (less than once a month for females, and about once a month for males) (Chapters 3 and 6). Students in Vietnam tend to use drinks with a moderate alcohol percentage (beer, wine) and on average consume 2-3 standard drinks per occasion (Chapters 3 and 6). In $12.5 \%$ of the drinkers, an AUDIT score of $\geq 8$ was detected; men are 14.3 times more likely to get an AUDIT score of $\geq 8$ than women (Chapter 2). However, the frequency of 6+ drinks per occasion (binge drinking) and the frequency of alcohol problems were less than once a month among these students (Chapter 5). These findings imply that many students in Vietnam drink and that there are considerable differences in heavy drinking between the genders. However, in general, the students do not drink frequently or heavily.

The consequences of alcohol use for drinkers and others are reported in Chapters 3 and 4 . Among five different types of harms, $75 \%$ of drinkers experienced at least one harm, and about one fifth experienced at least three different types of harms. The most common type of harm concerned immediate consequences such as 'loss of control, acute consequences, and withdrawal' and the least common type of harm was 'social conflict'. Male students experienced more harm than female students. In terms of harms inflicted by others (Chapter 4), most students had experience with at least one non-bodily harm in the previous year. The prevalence of non-bodily harm was twice as high as that of bodily harm. About one third of the population reported having experienced three to four types of non-bodily harms and about one tenth of the population reported two to three types of bodily harms due to the drinking of others. Students studying in the smaller cities (Hue and BMT) were more likely to experience both types of harms to others than students in the larger cities.

Age, gender and other social demographic variables were found to be predictors of alcohol consumption. The older students (aged $\geq 22$ years) were nearly twice as likely to report drinking than younger students ( $\leq 22$ years). Males were more likely to be drinkers, heavy drinkers and have experienced alcohol-related harms than females.

Chapter 5 investigates the relationship between alcohol expectancies, drinking motives and drinking outcomes. The coping motive had the strongest correlation with alcohol consumption. Among students in Vietnam, the link between alcohol expectancies and drinking outcomes was confirmed to be mediated by drinking motives. This finding implies that, also in Vietnam, although this country may have a 
different drinking culture than Western countries, drinking motives are still the final pathway to alcohol consumption.

In Chapter 6 a two-level model was tested to identify what proportion of variance in alcohol consumption per occasion is explained by variables at the individual level (including drinking motives and age) and at the level of drinking context (10 drinking context variables). Duration of drinking and coping motives showed the strongest correlation at the drinking context level and individual level, respectively. Additionally, when both drinking motives and drinking context were taken into account in one model, drinking context explained more variance in alcohol consumption per occasion than drinking motives. This finding implies that people seem to adjust their drinking according to the context.

The final chapter discusses our conclusions, the strengths and limitations of the studies, and implications for future research. An overview is presented of various aspects of alcohol consumption among Vietnamese students in different regions. The work in this thesis confirms the motivational theory of drinking, which was developed on the basis of studies from (mostly) Western countries. The findings presented here suggest that interventions are required at the national, school/university and also the individual level. At the national level, an alcohol policy should focus on restricting the availability of alcohol: e.g. a licensing system on retail sales, an increase in taxes on alcohol, and restrictions on the availability of alcohol by regulating the days and hours of retail sales. At the school and university level, awareness of the harmful consequences of alcohol use should be addressed through education, and/or the more informal internet network. At the individual level the AUDIT test, and drinking motives, should be used to screen students who drink and are at risk, in order to apply the most appropriate intervention. 
AMEN VAT'
'TING 
Schadelijk gebruik van alcohol staat wereldwijd in de top vijf van risicofactoren die tot ziekte, arbeidsongeschiktheid of overlijden kunnen leiden. Het alcoholgebruik is stabiel of neemt enigszins af in de ontwikkelde landen en neemt over het algemeen toe in ontwikkelingslanden. In Vietnam, een ontwikkelingsland, is het alcoholgebruik per jaar onder personen van 15 jaar en ouder (zowel geregistreerd als niet-geregistreerd) drastisch toegenomen van circa 1,6 liter in 1990 tot 6,6 liter in 2010 (een toename met $412 \%$ ).

Universiteitsstudenten (doorgaans tussen de 18 en 25 jaar oud) bevinden zich in een overgangsfase op weg naar volwassenheid en onafhankelijkheid. Deze periode wordt vaak gekenmerkt door toename van risicogedrag, zoals een buitensporige alcoholconsumptie. In veel studies in ontwikkelingslanden is gebleken dat universiteitsstudenten de neiging hebben om meer en zwaarder te drinken dan hun niet-studerende leeftijdsgenoten. Dit onderstreept de noodzaak drinkpatronen en de gevolgen daarvan alsook de belangrijkste voorspellers van het alcoholgebruik van studenten in kaart te brengen en effectieve preventiestrategieën te ontwikkelen.

In deze dissertatie is het PRECEDE-model gebruikt als een kader om de determinanten van het drinkgedrag van studenten te bepalen op zowel individueel als omgevingsniveau. Er worden vijf studies beschreven (hoofdstukken 2-6) die op basis van een cross-sectioneel ontwerp en zelfrapportages niet alleen drinkpatronen hebben onderzocht, maar ook de gevolgen daarvan, sociaaldemografische factoren en relevante determinanten. Daarnaast is de gecombineerde invloed van de verwachtingen van en de motieven voor alcoholgebruik onderzocht, evenals het verband tussen twee soorten individuele cognitieve determinanten en alcoholgebruik (hoofdstuk 5). In de studie in hoofdstuk 6 is het gecombineerde effect onderzocht dat individuele en omgevingsfactoren op drinkgedrag hebben. De data zijn verzameld tijdens studies (hoofdstukken 2 tot en met 4) onder studenten medicijnen aan de Medische Universiteit van Hanoi (Hanoi, Vietnam). In de hoofdstukken 5 en 6 worden de data beschreven die zijn verzameld in vier verschillende geografische clusters in Vietnam: i) Hanoi $(\mathrm{HN})$ in het noorden van het land (de politieke en culturele hoofdstad met een centrale, landelijke verzorgingsfunctie); ii) Ho Chi Minh (HCM) in het zuiden (de meest moderne stad met een centrale, landelijke verzorgingsfunctie); iii) Hue in het midden van het land (een historische traditionele stad met een provinciale verzorgingsfunctie), en iv) Buon Me Thuat (BMT) in de 
hooglanden in het zuiden (een stad met een provinciale verzorgingsfunctie in een afgelegen regio). In elk van deze clusters zijn data verzameld van at random geselecteerde groepen studenten van verschillende faculteiten (medicijnen, economie en technologie).

In de hoofdstukken 2 en 3 wordt de prevalentie van het alcoholgebruik beschreven. Meer dan de helft van de studenten had in het voorafgaande jaar alcohol gedronken (hoofdstukken 2 en 3) en de prevalentie van het drankgebruik was onder mannelijke studenten circa twee keer zo hoog als onder vrouwelijke studenten (hoofdstuk 3). Geconstateerd is echter dat studenten niet frequent drinken (minder dan één keer per maand voor vrouwen en ongeveer één keer per maand voor mannen) (hoofdstukken 3 en 6). Studenten in Vietnam nemen doorgaans drankjes met een gematigd alcoholpercentage (bier, wijn) en consumeren gemiddeld 2 -3 standaardglazen per keer (hoofdstukken 3 en 6). Bij 12,5\% van de drinkers is een AUDIT-score van $\geq 8$ (een indicatie van problematisch drinken) vastgesteld; het is voor mannen 14,3 keer waarschijnlijker dat zij een AUDIT-score van $\geq 8$ hebben dan voor vrouwen (hoofdstuk 2). De frequentie van meer dan 6 drankjes per keer (binge drinking) en de frequentie van alcoholproblemen onder deze studenten was echter minder dan één keer per maand (hoofdstuk 5). Deze bevindingen wijzen erop dat veel studenten in Vietnam alcohol drinken en dat er aanzienlijke verschillen in zwaar alcoholgebruik bestaan tussen mannelijke en vrouwelijke studenten. Over het algemeen drinken de studenten echter niet vaak of veel.

De gevolgen van het alcoholgebruik voor drinkers en voor anderen worden nader toegelicht in de hoofdstukken 3 en 4 . Van de vijf verschillende soorten schadelijke gevolgen ondervond $75 \%$ van de drinkers er minimaal één en circa een vijfde van de studenten gaf aan last te hebben gehad van ten minste drie soorten schadelijke gevolgen. De meest voorkomende schadelijke gevolgen betroffen directe gevolgen zoals 'controleverlies', 'acute gevolgen' en 'terugtrekkingsgedrag'; het minst voorkomende schadelijke gevolg was 'sociaal conflict'. Mannelijke studenten ondervonden meer schadelijke gevolgen dan vrouwelijke studenten. Wat schadelijke gevolgen betreft die door anderen werden veroorzaakt (hoofdstuk 4), hadden de meeste studenten ervaring met minimaal één niet-lichamelijk schadelijk gevolg in het voorafgaande jaar. De prevalentie van niet-lichamelijke schade was twee keer zo hoog als die van lichamelijke schade. Ongeveer een derde van de populatie gaf aan 
drie tot vier soorten niet-lichamelijke schade te hebben ondervonden en ongeveer een tiende rapporteerde twee tot drie soorten lichamelijke schade als gevolg van het drankgebruik van anderen. De kans op beide soorten schadelijke gevolgen door het drankgebruik van anderen was groter voor studenten in de kleinere steden (Hue en BMT) dan voor studenten in de grotere steden.

Leeftijd, sekse en andere sociaaldemografische variabelen bleken een voorspellende waarde voor alcoholgebruik te hebben. Oudere studenten ( $\geq 22$ jaar) rapporteerden bijna twee keer zoveel te drinken als jongere studenten $(\leq 22$ jaar). Mannen bleken veel vaker dan vrouwen drinkers en zware drinkers te zijn en hadden ook meer alcoholgerelateerde schade ondervonden.

In hoofdstuk 5 wordt het verband onderzocht tussen alcoholverwachtingen, drinkmotieven en het resulterende drankgebruik. Het coping-motief had de hoogste correlatie met alcoholgebruik. Gebleken is dat onder studenten in Vietnam het verband tussen alcoholverwachtingen en drankgebruik wordt beïnvloed door de drinkmotieven. Hoewel Vietnam wellicht een andere drinkcultuur kent dan de westerse landen, blijkt uit deze bevinding dat ook in dit land de motieven voor het drankgebruik uiteindelijk bepalend zijn voor de alcoholconsumptie.

In hoofdstuk 6 is een model met twee niveaus getest om in kaart te brengen welk percentage van de variantie in het alcoholgebruik per gebeurtenis wordt verklaard door variabelen op individueel niveau (waaronder drinkmotieven en leeftijd) en op het niveau van de context van het drankgebruik (op basis van 10 contextvariabelen). De duur van het drinken en coping-motieven vertoonden de hoogste correlatie op het niveau van de context van het drankgebruik respectievelijk het individuele niveau. Wanneer in een en hetzelfde model zowel de drinkmotieven als de context van het drankgebruik in aanmerking werden genomen, bleek bovendien dat die context per gebeurtenis meer variantie in het alcoholgebruik verklaarde dan de motieven voor het drankgebruik. Deze bevinding lijkt erop te duiden dat mensen hun drinkgedrag aan de context aanpassen.

In het laatste hoofdstuk worden onze conclusies besproken, evenals de sterke punten en de beperkingen van de studies en de implicaties voor toekomstig onderzoek. Er wordt een overzicht gegeven van uiteenlopende aspecten van alcoholgebruik onder Vietnamese studenten in verschillende regio's. De resultaten in deze dissertatie vormen een bevestiging van de motivationele theorie voor alcoholgebruik die 
ontwikkeld is op basis van studies in (voornamelijk) westerse landen. Uit de hier gepresenteerde bevindingen blijkt dat er interventies nodig zijn op zowel nationaal als school-/universiteitsniveau maar ook op individueel niveau. Op nationaal niveau zou in het alcoholbeleid de nadruk op beperking van de beschikbaarheid van alcohol moeten liggen, bijv. via een vergunningensysteem voor de verkoop in de detailhandel, hogere accijnzen op alcohol en regulering van de openingstijden/openingsdagen waarop in de detailhandel alcohol verkocht mag worden. Op het niveau van scholen en universiteiten zouden de schadelijke gevolgen van alcoholgebruik meer onder de aandacht moeten worden gebracht door voorlichting en/of via meer informele internetkanalen. Op individueel niveau zouden de AUDIT-test en drinkmotieven gebruikt moeten worden om studenten te screenen die alcohol drinken en daardoor risico's lopen, teneinde de meest adequate interventie toe te kunnen pass 